\title{
Pediatric surgical care: have we done enough?
}

"The Doctor", a classical painting from the $19^{\text {th }}$ century master Luke Fildes, depicts a physician at the bedside of a dying child with the parents as helpless onlookers. Any specialist that cares for children can immediately identify the mixed sense of anguish combined with a persistent, underlying drive for a cure and a passion to ease suffering. Few things unify people to the degree that is experienced in the care for a suffering child. The shifting paradigm away from individual efforts toward collaboration has resulted in rapid, greater advancements in the care of children in the past 20 years. The management of gastrointestinal pathology in children is no exception, with improved understanding of molecular mechanisms, biologic therapeutics and the advent of minimally invasive techniques. While some of these advances are extrapolated from adult data, others have arisen from the need for pediatric specific ailments. Understanding the differences in pathophysiology of a developing human is of paramount importance for these advancements.

A primary consideration in the surgical approach to pediatric patients is the size of the child. For open surgery, and even more so minimally invasive approaches, working space is dramatically decreased. Adding to the complexity is the limited selection of size specific devices for pediatric patients. Decreasing instrument component size raises a new set of engineering challenges that are hard to surmount, and the relative infrequency of pediatric disease processes makes economy of scale for production unrealistic. Consequently, pediatric device development is an industry abandoned by many companies.

All hope is not lost, however. The ever evolving need for decrease size of instruments in adults to minimize morbidity will indirectly impact the device development for children. This is perhaps best illustrated in the field of robotic surgery. The robotic platform makes complex movements easier and levels the playing field for surgeons with less inherent dexterity. The current robotic platforms are designed for adult patients, although pediatric surgical specialists have repurposed them in children. The quality of instruments has been refined, with $3 \mathrm{~mm}$ and $2 \mathrm{~mm}$ instruments that are sturdy and able to function like corresponding $5 \mathrm{~mm}$ instruments. Resolution of optics significantly increased, and image enhancement technologies have been developed. Furthermore, smaller energy devices and mechanical staplers have been specifically designed for children. These improvements combined with advancements in operative techniques have improved the care of the pediatric surgical patient.

As is so often the case in medicine, necessity drives innovation. We can only hope that this trend will continue to evolve in the future. The goal continues to be earlier, non-invasive diagnostics with more effective interventions that minimize patient morbidity and maximize patient comfort.

\section{Acknowledgments}

Funding: None.

\section{Footnote}

Provenance and Peer Review: This article was commissioned by the editorial office, Translational Gastroenterology and Hepatology for the series "Current Topics in Pediatric General Surgery". The article did not undergo external peer review.

Conflicts of Interest: All authors have completed the ICMJE uniform disclosure form (available at http://dx.doi.org/10.21037/ tgh-2021-01). The series "Current Topics in Pediatric General Surgery" was commissioned by the editorial office without any funding or sponsorship. Dr. Eduardo A. Perez served as the unpaid Guest Editor of the series and serves as an unpaid editorial board member of Translational Gastroenterology and Hepatology from Jan 2019 to Dec 2020. Dr. Samir Pandya served as the unpaid Guest Editor of the series. Dr. Matthew S. Clifton served as the unpaid Guest Editor of the series. Dr. Pandya is a consultant for robotic surgery company named Transenterix from April 2019 to April 2020. Dr. Clifton reports other from Bolder Surgical, LLC, outside the submitted work. The authors have no other conflicts of interest to declare.

Ethical Statement: The authors are accountable for all aspects of the work in ensuring that questions related to the accuracy or 
integrity of any part of the work are appropriately investigated and resolved.

Open Access Statement: This is an Open Access article distributed in accordance with the Creative Commons AttributionNonCommercial-NoDerivs 4.0 International License (CC BY-NC-ND 4.0), which permits the non-commercial replication and distribution of the article with the strict proviso that no changes or edits are made and the original work is properly cited (including links to both the formal publication through the relevant DOI and the license). See: https://creativecommons.org/ licenses/by-nc-nd/4.0/.

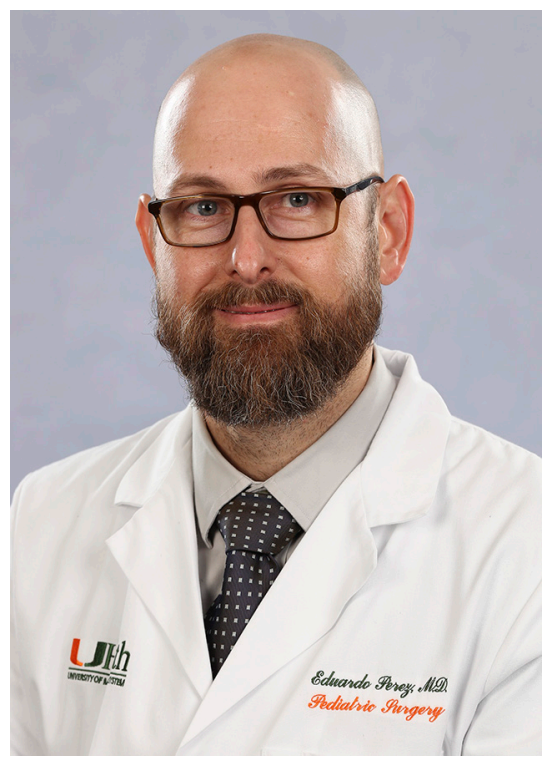

Eduardo A. Perez

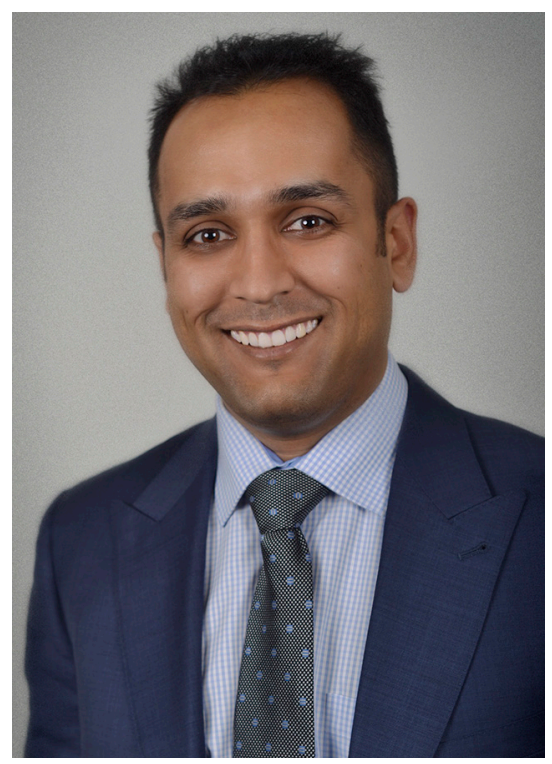

Samir Pandya

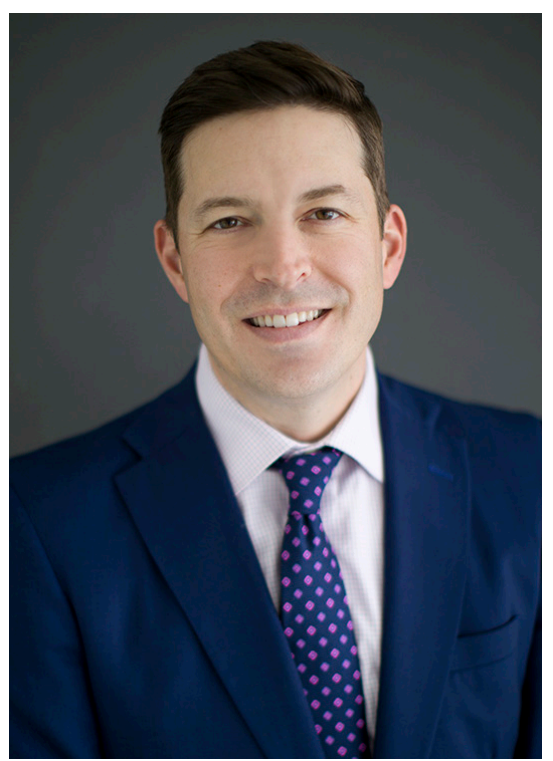

Matthew S. Clifton

Eduardo A. Perez, MD

Professor of Surgery, University of Miami, Miller school of Medicine, Miami, FL, USA

(Email: eperez3@med.miami.edu)

Samir Pandya, MD

Associate Professor of surgery UT Southwestern Medical Center, Dallas, Texas, USA

(Email: Samir:Pandya@UTSoutbwestern.edu)

Matthew S. Clifton, MD

Associate Professor of Surgery and Pediatrics, Emory University/Children's Healthcare of Atlanta, Atlanta, GA, USA

(Email: mclifto@emory.edu)

Received: 06 October 2020; Accepted: 06 November 2020; Published: 25 July 2021.

doi: 10.21037/tgh-2021-01

View this article at: http://dx.doi.org/10.21037/tgh-2021-01

doi: 10.21037/tgh-2021-01

Cite this article as: Perez EA, Pandya S, Clifton MS. Pediatric surgical care: have we done enough? Transl Gastroenterol Hepatol 2021;6:30. 